[cn]Chapter 11

\title{
[ch]Climate Change and Australian Urban Resilience: The Limits of Ecological Modernization as an Adaptive Strategy
}

[au]Jason Byrne, Brendan Gleeson, Michael Howes and Wendy Steele

\section{[a]Introduction}

Climate change in Australia has elicited a polarized response. As elsewhere, most Australians are transfixed by the looming threats and mind-numbing scale of likely changes. Some simply deny the risk, while a few have begun to make small changes at the household scale (e.g. energy efficient light-bulbs or appliances, green power, public transportation, recycling, solar hot water) (see Slocum, 2004, for a Canadian comparison). But very few signs suggest that Australian society has begun to take the urgent action required if we are to stave off catastrophic climate change (Low, 2008). The likely consequences for the world's driest continent are dire indeed: prolonged drought and episodic rainfall, heightened storm intensity, increased flooding, extreme heatwaves and frequent bushfires, severe coastal erosion, widespread insect-borne diseases (e.g. dengue fever, malaria and Ross River virus), failing food-bowls, climate refugees, unprecedented species extirpation and, ultimately, the need to abandon some settled areas (Allen Consulting Group, 2005; Australian Greenhouse Office, 2006; Buckley, 2007; Local Government Association of Queensland, 2007).

Australians are slowly awakening from the dream of unlimited prosperity to face the reality of ecological limits. We are confronted by an enormous challenge: how to adapt our settlements, agricultural systems and infrastructure to the coming changes. Urban areas will arguably feel the impacts of climate change the worst (Branz Ltd, 2007; Gill et al, 2007). As one of the most urbanized countries in the world, with over 
90 per cent of the population concentrated in towns and cities (Gleeson and Low, 2000; Australian Bureau of Statistics, 2008) Australia has much to lose from climate change. Our major cities are located close to or on the coast and many are highly vulnerable to climate change impacts (e.g. sea level rise, flooding and storm damage). While Australian planning has finally begun to take the first steps towards adapting our settlements to the future crisis, two crucial questions confront us: 'Are our actions too few or too late?' and 'How well can spatial planning respond to climate change challenges?’' (Bulkeley, 2006; Lyth, 2006).

In this chapter we outline some Australian planning responses to climate change, focusing on the resilience of Australian cities and their ability to respond to anticipated climate change impacts. ${ }^{1}$ We use the theoretical lens of ecological modernization, which proposes that economic growth can be decoupled from environmental harm via a technical, institutional and philosophical transformation. We consider how Australian planners have thus far addressed the challenges of adapting Australia's cities to cope with anticipated climate change impacts, acknowledging that many adaptive responses also have mitigative functions (e.g. decentralizing electricity generation via photovoltaic panels can lessen peak demand, lower emissions and reduce infrastructure vulnerability) (Hamin and Gurran, 2008). We begin by briefly examining urban coordination at the Commonwealth level and the impact of past federal policy on Australia's response to climate change. Next we consider the implications of the Commonwealth Government commissioned Garnaut report (Garnaut, 2008), which establishes the case for and efficacy of national emissions reduction targets, and subsequent policies for Australian planning. We then examine current federal, state and local responses, using South East Queensland (Australia’s fastest growing region) - and the Gold Coast specifically as a case study. 
Recognizing that adaptation will necessitate social change as well as policy and technological responses, and that climate change impacts will have social and environmental justice consequences, we discuss how Australian planners are tackling a range of climate change issues (e.g. climate responsive housing, more efficient transport systems, and infrastructure protection). We then consider why Australian planning systems have enabled or constrained adaptive responses to climate change. Our discussion illustrates how the nested scale of loosely coordinated policy responses actually plays out 'on-the-ground'. We conclude by considering what the Australian experience may offer the rest of the world.

\section{[a]Historical context}

Contrary to the common image of a sprawling rural nation, Australia is, and has long been, one of the world's most urbanized societies. Suburbanization occurred early from the late 19th century - and set the pattern for urban development and - for most people - everyday life from that point onwards. By 1900, around 50 per cent of Australians owned their homes, compared with just 10 per cent in the United Kingdom.

The suburban experience dominated national development and life during the 20th century and shows no sign of loosening its grip in the new millennium. The Australian suburban experience shares features with its counterparts in other developed nations for example, from the mid 20th century, a low density, car-based urban form and a social ecology marked by a high degree of 'familism'. And yet it also demonstrates unique qualities which help to explain the political and institutional responses to recently manifesting ecological threats, notably climate change. As the American scholar, Bruegmann (2005), points out, Australia appears to be the only developed country where the political left developed a strong attachment to - and advocacy for - 
suburbanization. For instance, leading late 20th century Australian urban scholars such as Hugh Stretton and Patrick Troy, drew upon social justice perspectives in support of suburbanization, which they argued delivered to the working class both material wealth and the resources for a good life. Australia also developed relatively stronger planning systems and mechanisms than did other settler societies, especially the USA, to guide suburban growth and ensure that it was equitable as well as timely (Bruegmann, 2005).

The Australian environmental movement grew out of this suburban experience but soon turned its back on its birthplace (Davidson, 2006). In recent decades, green critique has tended to cast suburbia in increasingly dystopian terms - a sprawling landscape of waste and natural destruction - tending to undermine and to some extent confuse progressive politics. Suburbanites largely ignored the increasingly shrill declamations of environmentalism and, in the past decade, a powerful new politics of ‘aspirational suburbia’ was encouraged and drawn upon by a conservative national government seeking to subordinate ecological concerns to the imperative of economic growth. For the Howard national government (1996-2007), the suburban constituency was assumed to value material welfare and personal improvement over ecological and shared social concerns. During this time, the 'Commonwealth' - as Australia's national government is known - withdrew from any active participation in urban policy, eschewing any concern for the planning of urban development and active shaping of (sub)urban consumption to achieve sustainability. National coordination of urban change was rejected in favour of a technocratic faith in improved resource efficiency which assumed markets and industries would deliver in a context of seemingly unfettered growth. In the latter years of the Howard government, the problems of uncoordinated urban growth came home to roost in the form of failing 
housing markets, infrastructure deficits and congested transport systems. Environmental concern, especially about climate change, swelled in suburbia. In 2007, the Howard government was defeated in a national election dominated by a mood of anxiety, even anger, in Australia's suburban heartlands.

The patchy record of urban coordination at the Commonwealth level in the last three decades is partly explained by the influence of ecological modernization (EM), or at least its weak variants, on national thinking. In the face of mounting evidence of environmental failure, EM has buttressed an embedded faith in technological innovation and market adjustment as superior alternatives to active coordination of economic growth and urban development. The newly elected Rudd national government (2007) has re-entered the field of national urban policy, but thus far only weakly, emphasizing for example, deficiencies in urban transport and energy infrastructure. Within Australia, urban environmental policy remains largely undeveloped.

[a]Policy environment - the ecological modernization frame

EM is a label that has been attached to a paradigm advocating social change towards sustainability. The term is not widely used outside academia but the ideas to which it refers have been highly influential in shaping many environmental policies, plans and management systems through its links to sustainable development (Hajer, 1995; Weale, 1998; Mol and Sonnenfeld, 2000; Grant and Papadakis, 2004). The core argument of EM is that although democracy, the state and the market have gone astray, they can be restructured in a way that will make them sustainable (Christoff, 1996; Mol and Spargen, 2000; Dryzek, 2005; Howes, 2005). EM argues that economic growth can be decoupled from raw material throughput, energy use and 
waste generation by applying new technology and redesigning institutions (Berger, et al, 2001; Dryzek, 2005; Howes, 2005).

Ecological modernization presumes that economic and environmental goals need not be mutually exclusive (Gouldson and Murphy, 1997; Curran, 2001). Well designed interventions by government are assumed not to hinder economic growth but instead to stimulate new and more efficient industries (Blowers, 1997; Weale, 1998; Mol and Sonnenfeld, 2000). Industry reduces its costs through increased technological efficiency and both the environment and community benefit from less pollution and waste. Governments continue their regulatory roles but are also recast as facilitators assisting industry to become more sustainable. New policies are directed towards correcting market failures by improving information on the impacts of actions, imposing green tax regimes to internalize negative externalities, and pricing ecological goods and services to reflect their 'true' value (Costanza et al, 1997; Lundqvist, 2000). Proponents strongly emphasize retaining the key institutions of modernity (science, technology, the market, industry and the state) but embedding ecologically-reformed economic practices within them (Berger et al, 2001).

Ecological modernization ranges from the original weak 'techno-corporatist' approach - focusing mainly on technological change, to the strong 'reflexive' approach that encourages a political transition to an 'ecological democracy' (Christoff, 1996; Dryzek, 2005). Many variants fall between these two extremes but adopt some elements from each (Fisher and Freudenburg, 2001). The differences between the strong and weak versions of EM can be illustrated by reviewing five core themes in EM programmes for social change:

[nl]1 Technological innovation to foster efficient resource use and reduce damage (which plays a substantial role in both the strong and weak versions); 
2 Providing economic imperatives as incentives for firms to improve their environmental performance (in both strong and weak versions);

3 Political and institutional change rendering policy making more open and flexible (modest in the weak version, substantial in the strong);

4 Transforming the role of social movements so they act as both watchdog and/or partner in decision making (in the strong version);

5 Discursive changes recasting environmental issues as opportunities to improve outcomes for the environment, business and the community (an essential aspect of the strong version).

[tx]These themes recur in various guises throughout a number of analyses (see Berger et al, 2001, pp58-59 and Welford and Hills, 2004, p325, for original material). However, only recently has the EM lens been directly applied to analysing policy and planning responses to climate change.

[a]Australia's national response to climate change

Weaker versions of EM underpinned the Australian government's policy commitment to 'Ecologically Sustainable Development' in the early 1990s (Howes, 2005). They also supported the initially positive response to the 1992 'Framework Convention on Climate Change', where the Keating Labor government believed that technological innovation alone would effect simple and rapid cuts to emissions with limited economic cost (Bulkeley, 2001; Christoff, 2005). The transition to the conservative Howard government in 1996 coincided with some disillusionment with this stance and led to a more restrained policy response until 2007. For example, voluntary programmes for energy conservation were established, a modest mandatory renewable energy target was set for the energy sector and, to placate the coal industry, funds were provided to research carbon capture and storage. In 2001, Australia joined the 
USA in abandoning the Kyoto Protocol and under pressure from growing public concern sought to establish the Asia-Pacific Partnership on Clean Development and Climate in 2006 as an alternative.

Following its election in 2007 and subsequent signing of the Kyoto Protocol, the Rudd Labor government embarked upon a year-long policy process to establish an emissions trading system. After it appointed Ross Garnaut (2008) to undertake the analysis and formulate discussion papers for public comment, the government released its final white paper in late 2008, committing Australia to cutting greenhouse gas (GHG) emissions by 5-15 per cent by 2020 and 60 per cent by 2050 (measured against a 2000 baseline) by:

[bl]** introducing a national emissions trading scheme covering 1000 of the major GHG emitters (that are responsible for 75 per cent of total national emissions) by 2010;

** establishing a $€ 250$ million fund to support research, development and deployment of carbon capture and storage technology;

** providing extra funds to help the energy sector and energy intensive export exposed firms adjust;

** funding further research into climate change by universities and the Commonwealth Scientific and Industrial Research Organisation (CSIRO);

** setting a target to generate 20 per cent of all energy from renewable sources by 2020;

** facilitating a climate adaptation strategy that includes $€ 6.5$ billion for a national 'Water for the Future’ plan;

** providing a €100 million 'International Forest Carbon Initiative' to assist developing countries protect forests as carbon sinks; 
** establishing domestic subsidies for household investments in solar hot water services, photovoltaic panels and rainwater tanks (initiatives that have been supported by the federal, state and local levels of government) (Australian Government, 2008). [tx]This set of policies clearly exhibits the weak ecological modernization assumptions on which they are founded, with a strong focus on technical innovation and research funding. The emission trading system promotes an economic incentive for producers and consumers to change their behaviour, but has no regulations to effect this response. Although the policy-making process has been extensive and open to public scrutiny, the ability of environmental groups to effectively influence the final targets has been curtailed by powerful energy and export sectors. There is little evidence of stronger versions of EM and there has been no move to undertake a major restructuring of government, nor has the role of social movements been transformed (although just getting the emissions trading system on the policy agenda was a major victory). And there is little evidence of a major shift in policy discourses - the major focus has been upon costs for industry rather than benefits to society or the environment.

Despite this set of policies, a coherent national strategy for climate change adaptation, engaging all levels of government, has yet to emerge. To implement the abovedescribed national framework, the Commonwealth government has relied upon the cooperation of state government heads through the Council of Australian Governments (COAG). The intent is to:

[bl]** improve government's ability to predict impacts;

** fund risk assessment programmes;

** fund programmes to develop adaptation strategies;

** educate decision makers and businesses; 
** develop policy tools for state and local levels of government.

[tx]To paraphrase the Commonwealth government, adaptive responses include; 'bearing the loss, sharing the loss, modifying the threat, preventing impacts, changing uses, changing location, research, and education’ (Allen Consulting Group, 2005, pp103-104). A key initiative of this strategy has been developing a national centre for climate change adaptation. According to COAG, the centre will: 'synthesise knowledge, coordinate and commission research, activities, broker research partnerships and provide information for decision makers in a form relevant to their sectoral or regional need'(Council of Australian Governments, 2007, p7). The primary aims then are to 'build adaptive capacity' and to 'reduce vulnerability'.

[b]National responsibilities

The Commonwealth government (hereafter Commonwealth) has taken the lead on identifying likely impacts of climate change and assessing vulnerabilities at a regional level - charging the CSIRO and Bureau of Meteorology (BOM) with this task. And the Commonwealth has also taken responsibility for developing a national digital elevation model for better predicting impacts and has developed a national water initiative for coordinating information on stream-flow and water availability. Local councils will soon be able to consult regional impact atlases that illustrate the likely climate change impacts in their area.

But most Commonwealth actions have been directed towards funding state and local governments to undertake risk assessment or implement adaptive responses. Although the Commonwealth has identified €9 billion for its climate change response, it has thus far only set aside €7.4 million over four years for this purpose (Australian Greenhouse Office, 2005). Local governments are eligible for 25,000 euro grants to undertake risk assessments - a paltry sum considering the scope and scale of the work 
required. Councils may also apply for a Community Water Grant to promote initiatives such as installing solar panels on school buildings and low flow showerheads, rainwater tanks and dual flush toilets in residential buildings. Another initiative has been to provide rebates (up to half the cost) to households for installing household photovoltaic power - which amounts to around $€ 4000$. And further rebates are available for solar hot water systems (about €500). Yet on-the-ground outcomes are scattered.

The Commonwealth has been mired in debates around the relative merits of mitigation (especially the national emissions trading scheme). The global economic crisis has hampered the Commonwealth's responses as the Rudd government has feared a voter backlash against spending on the environment. Investigative studies, policy reports, education strategies and economic levers (e.g. grants to state and local governments) have comprised the main actions, leading some CSIRO climate scientists, who estimate that a million homes are already at risk (Bardon, 2008), to plead for the Commonwealth government to override state and local governments to prevent development in future flood-prone areas and upon vulnerable coastlines through a national building code.

[b]State government responses and responsibilities

State governments (hereafter State) meanwhile have scrambled to respond to the existing impacts of climate change - especially the prolonged drought that has gripped most of the continent (the worst on record). Too numerous to detail here, some states have adopted similar strategies that merit closer attention, as do some unique responses. However, many strategies now identified as 'adaptation responses' were already enshrined in policy documents, strategies and plans - typically under the 
rubric of sustainability or smart growth - suggesting that the catalogue of state responses is as much rhetoric as action.

Queensland (Qld.), Victoria (Vic.) and Western Australia (WA) for example, have commissioned desalination plants - WA's is powered by wind energy but Queensland's is reliant upon coal power. Queensland has linked dwindling water resources through an integrated delivery grid and New South Wales (NSW) is adopting a similar approach. WA's adaptation response has largely been to gather more information and monitor the pace and scale of change, an approach also taken by Tasmania (Tas.) and the Northern Territory (NT). But some responses are unique. The NSW government has enacted carbon trading legislation, Tasmania has undertaken an audit of government emissions and the Australian Capital Territory (ACT) now requires full disclosure of building energy efficiency at the time of sale. These and other state government adaptation responses are summarized in Table 11.1.

[tab]Table 11.1 State government responses to climate change

\section{[c]Queensland's response}

Queensland's response typifies that of many other states. Queensland has set aside $€ 215$ million for climate change mitigation and adaptation - €150 million of which is reserved for a climate fund to generate annual funding for climate projects. The state released a climate change strategy in 2007 called 'Climate Smart 2050', which - like other Australian states - sets a target of reducing carbon emissions by 60 per cent of 2000 levels by the year 2050. The state has been investing heavily in clean coal and carbon capture technology (€150 million) as most electricity is generated from coal and Queensland exports enormous quantities of coal globally (currently earning the 
state €7.5 billion per annum) (Queensland Government, 2007). But solar, wind, geothermal and biomass technologies are also being funded - though currently to a lesser extent.

The Climate Smart strategy has established a number of adaptation measures including a ban on broadscale vegetation clearing and financial incentives for households to minimize water consumption and improve energy efficiency. For instance, until recently a Home Waterwise Scheme was in place. For a mere $€ 10$, a licensed plumber would visit a home and check for leaks, install a low-flow showerhead and water pressure regulator, and recommend water conservation measures. This scheme cost the state $€ 9$ million per annum but unfortunately has now been axed in the face of the global financial crisis and dwindling state coffers.

The Queensland government continues to subsidize domestic rainwater tanks, solar hot water systems and energy efficient appliances (e.g. front-loading washing machines). A million compact fluorescent light-bulbs have been given away to households as part of an education campaign, and the Sustainable Housing Code requires that all new housing is equipped with energy efficient lighting, efficient hot water (e.g. solar, gas or heat exchange) and water conserving devices. Demonstration sustainability houses have been constructed across the state to showcase these technologies; sub-tropical design incorporating passive ventilation is a strong feature (South East Queensland is expected to experience up to 30 days a year over 35 degrees Celsius by 2070 compared with the current three) (Local Government Association of Queensland, 2007; Australian Greenhouse Office, 2008).

The state government has also recently activated a state-of-the-art water recycling plant to recycle wastewater for commercial and domestic consumption and has established an electricity buy-back scheme where surplus power is purchased back 
from domestic photovoltaic installations at three times the domestic tariff (44 cents per kilowatt hour). The state has committed $€ 117$ million to an integrated regional cycling network and is expending large sums on light rail projects to improve public transport patronage. Transit oriented development and ‘smart growth' (e.g. compact urban forms and densification) are now enshrined as key land use planning strategies, such as the South East Queensland (SEQ) Regional Plan.

Just five years ago, the South East Queensland Regional Plan (2005-2026) contained only five references to climate change and GHGs - most of them referring to mitigation. The newly released Draft South East Queensland Regional Plan (20092031) has its primary regional policy now dedicated to climate change and sustainability; adaptation features prominently. The plan is a statutory document requiring local government town planning schemes to comply with its provisions. These provisions now include the development of a SEQ Regional Climate Change Management Plan, 'protection from climate hazards and protection of food supplies', 'compact urban form', transit equity, passive solar design and ventilation, requirements for risk analysis, extensive tree planting and better protection of - and access to - open space, to name just a few (The State of Queensland, 2008).

[b]Local government responses

The response at the local level has also been mixed. Once again, it is beyond the scope of this paper to document all local government responses, but some examples will illustrate the range of actions being taken - some duplicate national and state efforts.

For example, some Victorian councils (e.g. Wellington Shire) have attempted to place a moratorium on coastal development (later withdrawn due to resident and property developer opposition). The Melbourne City Council has constructed Australia’s first 
six-star green building with passive ventilation and cooling, solar power, natural lighting and vegetation walls (Council House 2). Some New South Wales councils have begun to designate areas specifically for habitat conservation, anticipating the likely impacts that climate change will have on biodiversity (Hamin and Gurran, 2008). Wyong Council (NSW) is establishing a buy-back fund for properties damaged by rising sea levels and the Greater Taree Council is determining its legal liability for past approvals of coast-front developments. The Ku-ring-gai Council has commenced harvesting stormwater to irrigate its parks and greenspaces. In Western Australia, the City of Melville has a grey-water re-use programme for similar purposes. South Australia’s Port Adelaide-Enfield Council has commissioned a flood risk study and its District Council of Yorke Peninsular recently refused a coastal development on the grounds of anticipated sea level rises. Finally, the Darwin City Council in the Northern Territory has developed an environmental management strategy to protect natural resources vulnerable to climate change impacts (SMEC Australia, 2007).

These examples show the wide variety of adaptive responses being taken at the local level. Our empirical focus on South East Queensland and the Gold Coast City Council demonstrates that local, regional and state coordination of some responses is beginning to occur, albeit in an ad-hoc and incremental fashion.

[c]Climate change adaptation on the Gold Coast

South East Queensland (SEQ) is the fastest-growing region in Australia (Department of Infrastructure and Planning, 2008). In the next two decades the region’s population is expected to increase by almost 2 million, from the current level of around 2.8 million - generating demand for over 700,000 new dwellings. This explosive growth is being driven by sea-change migration to the area's attractive landscapes, expanding economy and relaxed lifestyle associated with its sub-tropical climate. Although the 
region spans an area of $22,890 \mathrm{~km}^{2}$, the population is heavily concentrated in coastal towns and cities including Brisbane (Queensland's capital), and the Gold Coast (Australia’s sixth largest city). In reality, the largely suburban settlements from Noosa in the north to Coolangatta in the south are becoming a $200 \mathrm{~km}$ long conurbation (Spearitt, 2008).

A variety of landscapes characterize the region, including rainforest-covered extinct shield volcanoes, broad sandy beaches punctuated by headlands, extensive estuaries, mangrove-fringed rivers, and a wide coastal plain - some of which is still cultivated for sugar cane. Parts of the built environment are extremely susceptible to flooding; Brisbane and the Gold Coast have both sustained heavy damage in the past. And the Gold Coast which straddles a narrow coastal shoreline and broad floodplain is especially vulnerable (see Figure 11.1) (Godber, 2005).

[!insert fig 11.1 near here!]

[sc]Photo: Jason Byrne

[fig]Figure 11.1 Gold Coast built environment

[tx]Australia's glitzy tourist destination, the Gold Coast, is a strange amalgam of extravagant consumption (e.g. super-yachts, skyscraper apartments, canal-front mansions and 'ocean view jacuzzis'), tourism (swanky hotels, caravan parks, theme parks and ecotourism), beach culture (gold lame bikinis and world-renowned surfbreaks) and nature-oriented suburban living (e.g. family parks, shopping malls and palm-tasselled backyard pools). Some parts of the city are not dissimilar to Spain's Costa del Sol, Florida’s Fort Lauderdale or Mexico’s Cancún; others have more in common with Hawaii or Costa Rica. As the most biodiverse city in Australia, and the 
fastest growing settlement in the region, the city's climate change responses warrant closer inspection.

The Gold Coast City Council (GCCC) is pursuing a variety of mitigation and adaptation measures. As part of its commitment to the Cities for Climate Protection programme, Council has announced an ambitious goal to be carbon neutral by 2020 (GCCC, 2001, 2007). Although its adaptation responses have been widely praised, many were in fact pre-existing and linked to sustainability objectives (e.g. Local Agenda 21). For example, GCCC has a longstanding partnership with the Queensland State Government for a beach re-nourishment programme to replenish beaches suffering erosion. And its town planning scheme has pre-existing planning policies and guidelines to manage coastal and flood-prone development (e.g. dune revegetation, water sensitive urban design and mosquito control). For instance, new beachfront houses have long been required to install a protective rock wall behind the coastal dunes - able to withstand a 1 in 50 year storm event (i.e. large cyclone). Yet GCCC often cites this as a climate change adaptation.

But some of GCCC's climate change responses are new. It has backed sustainable housing demonstration projects (three thus far - see Figure 11.2), is undertaking water and energy efficiency initiatives for its buildings, and is installing light emitting diodes in the city's traffic lights to reduce electricity consumption. Its swimming pools will soon be heated using solar heating and its beachfront barbecue facilities will be upgraded to energy efficient appliances. GCCC is raising the wall of the city’s main dam - the Hinze Dam - to increase its storage capacity and to mitigate downstream flooding, and now has a policy requiring an additional $27 \mathrm{~cm}$ of building floor clearance above the state's 1 in 100 year ARI flood level (based on CSIRO modelling). In conjunction with the state government, GCCC is establishing a 
Sustainable Housing Code that will cover all new houses built on the Gold Coast and has established a series of wildlife corridors to preserve ecological connectivity between the coast and the hinterland rainforests. Finally, the new desalination plant (funded partly by GCCC and partly by the state) is also an adaptive measure - though a dubious one given its coal-fired power-source.

[!insert fig 11.2 near here!]

[sc]Photo: Jason Byrne

[fig]Figure 11.2 Sustainable house, Gold Coast

[a]Planning systems issues and adaptive strategies

Why then is planning for climate change in Australia so fragmented, and why have the land use planning responses been so late? Australian systems of governance and the various planning systems operating within the country are partly responsible. Unlike the United Kingdom or New Zealand, the Australian Commonwealth government has no constitutionally defined planning powers or obligations. Neither, however, is it prevented or hindered by the constitution from undertaking urban policy. Instead, like the United States, planning has largely been a 'state concern'. In Australia, the seven states and two territories have promulgated different types of planning legislation. Although there are some similarities between these sub-national systems, no two are the same (for a comprehensive review see Gurran, 2007).

Most Australian states and territories have metropolitan planning instruments, regional planning instruments, state planning policies of various forms and building codes. With the exception of Queensland, Australian planning systems are largely prescriptive in nature. Enabling legislation typically provides for land use planning and management through a town planning scheme, usually administered by local 
government (a level of government constituted by the state and lacking its own constitutional basis). These schemes zone land parcels for prescribed uses. These land uses are controlled through a zoning and development table setting out development standards (e.g. boundary setbacks, building heights, parking requirements etc.). Queensland however, like New Zealand and some US states, has a performance-based planning system. Land use planning schemes in Queensland establish desired environmental outcomes and performance objectives that land and property developers use to guide their developments and comply with the intent of the scheme (Baker et al, 2006). Until recent amendments were made to the Integrated Planning Act (1997), very few forms of development were prohibited in Queensland.

Despite the style of planning system adopted by each state, the effect of these arrangements has been to divide up responsibilities in ways that can often hamper efficient responses to problems like climate change. State governments are dependent upon the Commonwealth for funding, but ardently defend their interests and protect their autonomy. If the Commonwealth desires unified action it must broker deals with the states or cajole them into complying with national interests. And actions across state borders - which pay no heed to river catchments, conurbations or biogeochemical processes - can be difficult to achieve. As can be seen from our discussion of national, state and local responses to climate change, efforts can be duplicated and responsibilities hard to determine - with subsequent buck-passing across all three levels.

[a]From the local to the global: Lessons from the Australian experience The legacy of the Howard national government was urban policy that was left largely to the states and territories, even though its own policy settings (e.g. immigration) profoundly shaped the course of metropolitan development. At the state level, urban 
policy in recent decades has fixed on the ideal of 'urban consolidation' (compaction) as a means to achieve efficiency and sustainability in the urban system (see Green and Handley, Chapter 4). Consolidation has been the leading principle of metropolitan scale planning through the 1990s and beyond, exemplified for example in the new draft South East Queensland Regional Plan 2009-2031, which seeks to contain the metropolitan footprint of Brisbane and its connected urban sub-regions (Ipswich, Gold Coast and Sunshine Coast) and to increase the share of new housing supply in brownfield redevelopment areas.

It can be argued that the long fixation on urban form, especially density, in Australian metropolitan planning has been to the detriment of critical urban structural issues, including the fundamental layout of land uses and the distribution and ranking of urban centres (Troy, 1996). Australia's large, complex metropolitan regions have developed increasingly problematical structures due to over-centralization of investment, economic activity and travel behaviour. Arguably, the fixation on consolidation (i.e. densification) as a dominant urban policy setting reflects faith in a weak version of ecological modernization (EM). The idea that growth can be improved, not curbed, and made sustainable through technological adjustments to the built environment can be read as a variant of EM strategy.

The consolidation policy setting has only opposed outward growth, not growth per se, as reflected in the increasing massification and intensification of the metropolitan environment via densification. Yet hand in hand with densification, residents of Australian cities like the Gold Coast continue to consume more energy and generate higher greenhouse emissions (Australian Conservation Foundation, 2007). Such trends are also evident in the United States and Europe. Increasing evidence of policy failure suggests the need for a more critical and directive view to urban growth and 
climate change that addresses the fundamental problems of overconsumption and overproduction in household and commercial sectors - not just technological tinkering with the symptoms.

A shift to a new decentralized urban structure in metro regions seems desirous as a means for fundamentally lowering energy consumption by facilitating the localization of economic activity, food production and waste management. Ultimately, however, there appears no simple 'spatial fix' for problems like greenhouse emissions. Planning will need to work in concert with political economic policies that reshape the fundamental causes of overconsumption and overproduction. Consistent with stronger versions of EM, this will require major shifts in policy discourse as well as a fundamental rethink of prevailing governance processes. Challenging questions about how to distribute the burden of environmental adjustments within Australian and global human settlements must also be raised.

[a]Conclusion: After the horse has bolted...

Fortunately it is not too late to do something about climate change, and Australian planners have begun to tackle the many challenges associated with mitigation and adaptation. Most Australian states either have or are in the process of developing climate change adaptation strategies. Many are pursuing diverse actions such as fostering research and monitoring, educating their constituents, promoting transit oriented development, and providing incentives for household-scale adaptive responses (e.g. water conservation and energy efficiency). Some have taken very progressive actions such as developing energy efficiency ratings for buildings and mandating their disclosure at the time of sale, promoting the retention and enhancement of urban forests (ACT), linking water resources into an integrated grid (Qld.), mandating rainwater tank use (SA), and phasing out electric hot water systems 
(Qld., NSW, ACT). But few have taken the regulatory pathway, preferring instead to use incentives, rebates, education and demonstration projects to effect change. Arguably an area with greater potential for climate change adaptation is in land use planning. The planning responses taken thus far include risk analysis and minimization, education, monitoring, reporting, new codes and standards, new assessment methods, improved coordination, and integrated emergency response / disaster planning. But as we have seen, strategies such as urban consolidation or building desalination plants can have paradoxical and perverse consequences - that is, reducing carbon sinks and habitat patches and increasing energy use (Hamin and Gurran, 2008). While reducing lot sizes has been a goal of most metropolitan plans over the past decade - allowing for more efficient use of infrastructure - it may actually have promoted less efficient and more vulnerable urban landscapes. The 'affluenza' that gripped Australian society during the economic boom has meant bigger houses, smaller gardens, larger and more appliances (e.g. flat screen TVs and clothes dryers), consumption oriented lifestyles and less greenspace. We may actually be worse off as a result of consolidation.

Ecological modernization - the idea of decoupling economic growth from environmental harm - has been the primary strategy for climate change adaptation and mitigation in Australia thus far. And it has been weak, not strong ecological modernization ideas that have driven climate change strategies at all levels of government. Energy conservation, transit-oriented development and urban consolidation are all technologies that embody ideas of eco-efficiency. But in many ways unfettered growth and economic prosperity without large-scale lifestyle changes or the pain of seriously reworking the way we interact with Australian socio-political and biogeochemical systems is a path to disaster. 
Noticeably absent from Australian adaptive responses are initiatives such as identifying areas that may have to be abandoned and areas where new development will be prohibited, retrofitting existing building stock to bolster resilience to climate change impacts, and developing uniform climate-change building codes for higher intensity cyclones, heatwaves, storm surges, flooding and so on. Problematically, there is an assumption across the Australian adaptation literature that buildings have a 20 to 50 year lifespan. In reality, many Australian cities have buildings much older than that. Adaptation must therefore ensure that existing buildings are retrofitted with insulation, water- and energy-efficient devices and upgraded to meet new building codes (e.g. replacing roofs that are susceptible to hail damage). The option of strategically abandoning some areas or buying back the most vulnerable sites and relocating communities must also be seriously considered.

Perhaps most concerning about the way that Australian state governments have addressed climate change adaptation thus far has been their total neglect of environmental and social justice issues. Impoverished and ethno-racially marginalized communities have the most to lose from climate change. While wealthy communities located on the coast or next to estuaries and canals will undoubtedly suffer - at least they will have the resources to escape or rebuild. Remote Aboriginal settlements and immigrant and impoverished communities confined to older housing stocks that lack thermal efficiency, relegated to areas far from social and community services and lacking public transportation, will be seriously impacted by climate change. Heatwaves, increased costs of electricity and water, flooding, storm damage and spreading vector-borne diseases will take a heavy toll on these communities. They will disproportionately carry the burden unless governments expand adaptation measures to include affordable housing, healthcare, better access to transportation and 
urban greenspaces, and act to curb conspicuous consumption and profligate growth. Future research must address these issues.

[a]Note

1 Resilience refers to the ability of cities to respond to, adapt to and recover from stress and catastrophic events related to climate change (e.g. violent storms, heatwaves, large scale flooding and epidemics). Resilient cities will 'bounce back' from such events without suffering high death-rates and/or long-term damage to critical infrastructure, the integrity of life-sustaining systems and social institutions (Alberti and Marzluff, 2004; Campanella, 2006; Commonwealth Scientific and Industrial Research Organisation et al, 2007).

[a]References

Alberti, M. and Marzluff, J. M. (2004) 'Ecological resilience in urban ecosystems: Linking urban patterns to human and ecological functions', Urban Ecosystems, vol 7, no 3, pp241-265

Allen Consulting Group (2005) 'Climate change risk and vulnerability: Promoting an efficient response in Australia', Australian Greenhouse Office, Department of the Environment and Heritage, Canberra

Australian Bureau of Statistics (2008) 'Australian social trends, 2008', www.abs.gov.au/AUSSTATS/abs@.nsf/Lookup/4102.0Chapter3002008, accessed 15 December 2008

Australian Government (2008) 'Carbon Pollution Reduction Scheme: Australia’s low carbon future', Commonwealth of Australia, Attorney General’s Department, Canberra

Australian Greenhouse Office (2005) ‘National Climate Change Adaptation Program’, Department of Environment and Heritage, Canberra 
Australian Greenhouse Office (2006) 'Adaptation planning for climate change', Australian Planner, vol 43, no 2, pp8-9

Australian Greenhouse Office (2008) 'Australia's settlements and infrastructure: Impacts of climate change', www.greenhouse.gov.au/impacts/settlements/html, accessed 1 August 2008

Baker, D. C., Sipe, N. G. and Gleeson, B. (2006) 'Performance-based planning: Perspectives from the United States, Australia and New Zealand', Journal of Planning Education and Research, vol 25, no 4, pp396-409

Bardon, J. (2008) 'Call for climate change planning code’, Australian Broadcasting Corporation, www.abc.net.au/news/stories/2008/10/27/2402714.htm, accessed 27 October, 2008

Berger, G., Flynn, A., Hines, F. and Johns, R. (2001) ‘Ecological modernization as a basis for environmental policy: Current environmental discourse and policy and the implications on environmental supply chain management', Innovation, vol 14, no 1, pp55-72

Blowers, A. (1997) 'Environmental policy: Ecological modernisation or risk society?' Urban Studies, vol 34, nos 5-6, pp845-871

Branz Ltd (2007) 'An assessment of the need to adapt buildings for the unavoidable consequences of climate change', Australian Greenhouse Office, Department of the Environment and Water Resources, Canberra

Bruegmann, R. (2005) Sprawl: A Compact History, University of Chicago Press, Chicago

Buckley, R. (ed) (2007) Climate Response: Issues, Costs and Liabilities in Adapting to Climate Change in Australia, Griffith University, Gold Coast 
Bulkeley, H. (2001) 'No regrets?: Economy and environment in Australia’s domestic climate change policy process', Global Environmental Change, vol 11, no 2, pp155-169

Bulkeley, H. (2006) 'A changing climate for spatial planning', Planning Theory and Practice, vol 7, no 2, pp203-214

Campanella, T. J. (2006) 'Urban resilience and the recovery of New Orleans’, Journal of the American Planning Association, vol 72, no 2, pp141-146

Christoff, P. (1996) 'Ecological modernisation, ecological modernities', Environmental Politics, vol 5, no 3, pp476-500

Christoff, P. (2005) 'Policy autism or double-edged dismissiveness?: Australia's climate policy under the Howard government', Global Change, Peace and Security, vol 17, no 1, pp29-44

Commonwealth Scientific and Industrial Research Organisation, Arizona State University and Stockholm University (2007) Urban Resilience: Research Prospectus. A Resilience Alliance Initiative for Transitioning Urban Systems towards Sustainable Futures, Commonwealth Scientific and Industrial Research Organisation, Canberra

Costanza, R., d’Arge, R., de Groot, R., Farber, S., Grasso, M., Hannon, B., Limburg, K., Naeem, S., O’Neill, R. V., Paruelo, J., Raskin, R. G., Sutton, P. and van den Belt, M. (1997) ‘The value of the world’s ecosystem services and natural capital', Nature, vol 387, no 6630, pp253-260

Council of Australian Governments (2007) 'National Climate Change Adaptation Framework’, Australian Government

Curran, G. (2001) 'The third way and ecological modernisation', Contemporary Politics, vol 7, no 1, pp41-55 
Davidson, A. (2006) 'Stuck in a cul-de-sac? Suburban history and urban sustainability in Australia', Urban Policy and Research, vol 24, no 2, pp201-216

Department of Infrastructure and Planning (2008) 'South East Queensland', www.dip.qld.gov.au/seq, accessed 15 December 2008

Dryzek, J. (2005) The Politics of the Earth: Environmental Discourses, Oxford University Press, Oxford

Fisher, D. R. and Freudenburg, W. R. (2001) 'Ecological modernization and its critics: Assessing the past and looking towards the future', Society and Natural Resources, vol 14, no 8, pp701-709

Garnaut, R. (2008) The Garnaut Climate Change Review - Financial Report, Cambridge University Press, Melbourne

Gill, S., Handley, J., Ennos, R. and Pauleit, S. (2007) 'Adapting cities for climate change: The role of green infrastructure', Built Environment, vol 33, no 1, pp115-133

Gleeson, B. and Low, N. (2000) Australian Urban Planning: New Challenges, New Agendas, Allen and Unwin, St Leonards, NSW

Godber, A. (2005) 'Urban floodplain land-use - acceptable risk?' The Australian Journal of Emergency Management, vol 20, no 3, pp22-40

Gold Coast City Council (2001) 'The Gold Coast 2010 Cities for Climate Protection Program: 2001 Action Plan’, Gold Coast City Council, Gold Coast

Gold Coast City Council (2007) 'Carbon neutral by 2020: Gold Coast City Council responding to climate change’, Gold Coast City Council, Gold Coast

Gouldson, A. and Murphy, J. (1997) 'Ecological modernization: Restructuring industrial economics', in M. Jacobs (ed) Greening the Millennium? The New Politics of the Environment, Blackwell Publishers, Oxford, pp74-86 
Grant, R. and Papadakis, E. (2004) 'Challenges for global environmental diplomacy in Australia and the European Union', Australian Journal of International Affairs, vol 58, no 2, pp279-292

Gurran, N. (2007) Australian Urban Land Use Planning: Introducing Statutory Planning Practice in New South Wales, Sydney University Press, Sydney

Hajer, M. (1995) The Politics of Environmental Discourse: Ecological Modernization and the Policy Process, Clarendon Press, Oxford

Hamin, E. M. and Gurran, N. (2008) 'Urban form and climate change: Balancing adaptation and mitigation in the U.S. and Australia', Habitat International, doi:10.1016/j.habitatint.2008.10.005, online

Howes, M. (2005) Politics and the Environment: Risk and the Role of Government and Industry, Earthscan Press, London

Local Government Association of Queensland (2007) 'Adapting to climate change: A Queensland local government guide’, Local Government Association of Queensland, Brisbane

Low, N. (2008) 'In praise of public planning in an era of climate change', Urban Policy and Research, vol 26, no 2, pp141-144

Lundqvist, L. (2000) ‘Capacity building or social construction? Explaining Sweden's shift towards ecological modernisation', Geoforum, vol 31, no 1, pp21-32

Lyth, A. (2006) 'Climate proofing Australian urban planning: Working towards successful adaptation', Australian Planner, vol 43, no 2, pp12-15

Mol, A. P. J. and Sonnenfeld, D. A. (2000) 'Ecological modernisation around the world: An introduction', Environmental Politics, vol 9, no 1, pp3-14

Mol, A. P. J. and Spargen, G. (2000) 'Ecological modernisation', Environmental Politics, vol 9, no 1, pp17-49 
Queensland Government (2007) 'Climate Smart 2050: Queensland climate change strategy 2007’, State Government of Queensland

Slocum, R. (2004) 'Polar bears and energy efficient lightbulbs: Strategies to bring climate change home', Environment and Planning D: Society and Space, vol 22, no 3, pp413-438

SMEC Australia (2007) 'Climate change adaptation actions for local government', Australian Greenhouse Office, Department of the Environment and Water Resources, Canberra

Spearitt, P. (2008) 'The water crisis in South East Queensland', in P. Troy (ed) Troubled Waters: Confronting the Water Crisis in Australia's Cities, Australian National University E-Press, Canberra

The State of Queensland (2008) 'Draft South East Queensland Regional Plan', Department of Infrastructure and Planning, Brisbane

Troy, P. (1996) The Perils of Urban Consolidation: A Discussion of Australian Housing and Urban Development Policies, The Federation Press, Sydney

Weale, A. (1998) 'The politics of ecological modernization', in J. Dryzek and D. Schlosberg (eds) Debating the Earth: The Environmental Politics Reader, Oxford University Press, Oxford, pp301-318

Welford, R. and Hills, P. (2004) ‘Ecological modernisation, environmental policy and innovation priorities for the Asia Pacific Region', International Journal of Environment and Sustainable Development, vol 2, no 3, pp324-340 
Table 1 - State responses to climate change

\begin{tabular}{|c|c|c|c|c|c|c|c|c|}
\hline & Queensland & New South Wales & $\begin{array}{l}\text { Australian } \\
\text { Capital } \\
\text { Territory } \\
\end{array}$ & Victoria & Tasmania & South Australia & $\begin{array}{l}\text { Western } \\
\text { Australia }\end{array}$ & $\begin{array}{l}\text { Northern } \\
\text { Territory }\end{array}$ \\
\hline $\begin{array}{l}\text { Adaptation } \\
\text { strategy }\end{array}$ & $\begin{array}{l}\text { Climate Smart } \\
2050\end{array}$ & $\begin{array}{l}\text { Greenhouse Plan } \\
2005\end{array}$ & $\begin{array}{l}\text { Weathering the } \\
\text { Change 2007- } \\
2025\end{array}$ & $\begin{array}{l}\text { Our } \\
\text { Environment } \\
\text { Our Future } \\
\text { Action Plan }\end{array}$ & $\begin{array}{l}\text { Framework for } \\
\text { Action on } \\
\text { Climate Change }\end{array}$ & $\begin{array}{l}\text { Greenhouse } \\
\text { Strategy 2007- } \\
2020\end{array}$ & $\begin{array}{l}\text { Making Decisions } \\
\text { for the Future } \\
(2007)\end{array}$ & $\begin{array}{l}\text { Strategy } \\
\text { under } \\
\text { development }\end{array}$ \\
\hline Climate fund & 151 million Euro & 171 million Euro & None & None & None & None & None & None \\
\hline Legislation & $\begin{array}{l}\text { Vegetation } \\
\text { Management Act } \\
(1999)\end{array}$ & $\begin{array}{l}\text { ** Carbon Rights } \\
(1998) \\
\text { ** Native } \\
\text { Vegetation Act } \\
(2003)\end{array}$ & None & None & $\begin{array}{l}\text { Climate Change } \\
\text { State Action Act } \\
(2008)\end{array}$ & $\begin{array}{l}\text { Climate Change } \\
\text { and Greenhouse } \\
\text { Emissions } \\
\text { Reduction Act } \\
\text { (2007) }\end{array}$ & $\begin{array}{l}\text { ** Carbon Rights } \\
\text { Act (2003) } \\
* * \text { Tree } \\
\text { Plantations } \\
\text { Agreement Act } \\
\text { (2003) }\end{array}$ & None \\
\hline $\begin{array}{l}\text { Research } \\
\text { initiatives }\end{array}$ & $\begin{array}{l}\text { ** Clean coal } \\
* * \text { Geothermal } \\
* * \text { Fuel cell } \\
\text { ** Cloud seeding } \\
\text { ** Livestock }\end{array}$ & $\begin{array}{l}\text { ** Bushfires } \\
* * \text { Water } \\
* * \text { Biodiversity } \\
\text { ** Weeds and } \\
\text { pests } \\
* * \\
\text { Geosequestration }\end{array}$ & $\begin{array}{l}\text { ** Urban } \\
\text { impacts }\end{array}$ & $\begin{array}{l}\text { ** Carbon } \\
\text { storage } \\
\text { ** Agricultural } \\
\text { adaptations } \\
\text { ** Impact } \\
\text { modelling }\end{array}$ & $\begin{array}{l}\text { ** } \\
\text { Biosequestration } \\
* * \text { Agriculture } \\
\text { ** Antarctic } \\
\text { impacts }\end{array}$ & $\begin{array}{l}\text { ** Dryland } \\
\text { salinity }\end{array}$ & $\begin{array}{l}* * \text { Emissions } \\
\text { reduction } \\
* * \text { Geothermal } \\
* * \text { Biodiesel } \\
* * \text { Methane } \\
\text { capture } \\
* * \\
\text { Biosequestration }\end{array}$ & None \\
\hline $\begin{array}{l}\text { Environmental } \\
\text { measures }\end{array}$ & $\begin{array}{l}\text { ** Tree clearing } \\
\text { ban } \\
* * \text { Reafforestation } \\
\text { ** New national } \\
\text { parks } \\
\text { ** Wildlife } \\
\text { corridors }\end{array}$ & $\begin{array}{l}\text { ** Tree clearing } \\
\text { ban } \\
\text { ** Tree } \\
\text { plantations } \\
\text { ** Farm forestry } \\
\text { ** Wildlife } \\
\text { corridors }\end{array}$ & $\begin{array}{l}\text { ** Tree clearing } \\
\text { ban } \\
* * \\
\text { Reafforestation } \\
\text { ** Bushfire } \\
\text { abatement } \\
\text { ** Homeowner } \\
\text { incentives } \\
\text { ** Wildlife } \\
\text { corridors } \\
\end{array}$ & $\begin{array}{l}* * \text { Vegetation } \\
\text { mapping } \\
* * \\
\text { Reafforestation } \\
* * \text { New national } \\
\text { parks } \\
* * \text { Wildlife } \\
\text { corridors } \\
* * \text { Catchment } \\
\text { management } \\
\end{array}$ & $\begin{array}{l}* * \text { Forest } \\
\text { management }\end{array}$ & $\begin{array}{l}\text { ** } \\
\text { Reafforestation } \\
* * \text { Conservation } \\
\text { strategy } \\
\text { ** Forecast } \\
\text { habitat impacts }\end{array}$ & $\begin{array}{l}* * \text { Monitoring } \\
\text { fisheries impacts } \\
* * \text { Conservation } \\
\text { strategy }\end{array}$ & $\begin{array}{l}* * \text { Vegetation } \\
\text { management }\end{array}$ \\
\hline $\begin{array}{l}\text { Education } \\
\text { program }\end{array}$ & $\begin{array}{l}\text { ** Awareness } \\
\text { campaign } \\
* * \text { Behavioural } \\
\text { change } \\
* * \text { School } \\
\text { curriculum }\end{array}$ & $\begin{array}{l}\text { ** Awareness } \\
\text { campaign } \\
* * \text { Behavioural } \\
\text { change } \\
\text { ** Farmer training } \\
\text { ** School }\end{array}$ & $\begin{array}{l}\text { ** Awareness } \\
\text { campaign } \\
* * \text { Behavioural } \\
\text { change }\end{array}$ & $\begin{array}{l}\text { ** Awareness } \\
\text { campaign } \\
* * \text { Behavioural } \\
\text { change }\end{array}$ & $\begin{array}{l}\text { ** Awareness } \\
\text { campaign } \\
\text { ** Behavioural } \\
\text { change } \\
\text { ** School } \\
\text { curriculum }\end{array}$ & $\begin{array}{l}* \text { Awareness } \\
\text { campaign } \\
\text { ** Behavioural } \\
\text { change } \\
\text { ** School } \\
\text { curriculum }\end{array}$ & $\begin{array}{l}\text { ** Awareness } \\
\text { campaign }\end{array}$ & $\begin{array}{l}* * \\
\text { Behavioural } \\
\text { change }\end{array}$ \\
\hline
\end{tabular}




\begin{tabular}{|c|c|c|c|c|c|c|c|c|}
\hline & Queensland & New South Wales & $\begin{array}{l}\text { Australian } \\
\text { Capital } \\
\text { Territory } \\
\end{array}$ & Victoria & Tasmania & South Australia & $\begin{array}{l}\text { Western } \\
\text { Australia }\end{array}$ & $\begin{array}{l}\text { Northern } \\
\text { Territory }\end{array}$ \\
\hline & & curriculum & & & $\begin{array}{l}\text { ** Training } \\
\text { programs }\end{array}$ & $\begin{array}{l}\text { ** Training } \\
\text { programs }\end{array}$ & & \\
\hline $\begin{array}{l}\text { Water } \\
\text { resources }\end{array}$ & $\begin{array}{l}\text { ** Water } \\
\text { efficiency rebates } \\
* * \text { Water } \\
\text { restrictions } \\
* * \\
\text { Overconsumption } \\
\text { fines } \\
\text { ** Rainwater tank } \\
\text { rebate } \\
\text { ** Desalination } \\
\text { ** New dams } \\
\text { ** Water grid } \\
\text { ** Wastewater } \\
\text { recycling }\end{array}$ & $\begin{array}{l}* * \text { Water } \\
\text { efficiency } \\
\text { standards } \\
* * \text { Water } \\
\text { restrictions } \\
\text { ** Water grid }\end{array}$ & $\begin{array}{l}* * \text { Water } \\
\text { efficiency }\end{array}$ & $\begin{array}{l}* * \text { River } \\
\text { protection } \\
\text { legislation } \\
* * \text { Water } \\
\text { restrictions }\end{array}$ & $\begin{array}{l}* * \text { Water } \\
\text { efficiency } \\
* * \text { Rainwater } \\
\text { tanks } \\
* * \text { Review of } \\
\text { water allocation } \\
\text { plans } \\
\text { ** Water } \\
\text { restrictions }\end{array}$ & $\begin{array}{l}* * \text { Water } \\
\text { efficiency } \\
* * \text { Water } \\
\text { restrictions }\end{array}$ & $\begin{array}{l}\text { ** Desalination } \\
* * \text { Wastewater } \\
\text { recycling } \\
* * \text { Consumption } \\
\text { targets }\end{array}$ & $\begin{array}{l}* * \text { Water } \\
\text { efficiency }\end{array}$ \\
\hline $\begin{array}{l}\text { Energy } \\
\text { measures }\end{array}$ & $\begin{array}{l}* * \text { Energy } \\
\text { efficiency } \\
\text { standards } \\
\text { ** Renewable } \\
\text { energy targets } \\
\text { ** Clean coal } \\
\text { ** Electric water } \\
\text { heater ban } \\
\text { ** Solar feed in } \\
\text { tariff } \\
\text { ** Compact } \\
\text { fluorescent bulb } \\
\text { giveaway } \\
\text { ** Natural gas } \\
\text { rebate } \\
\text { ** Smart meters }\end{array}$ & $\begin{array}{l}\text { ** Energy } \\
\text { efficiency } \\
\text { standards } \\
\text { ** Light emitting } \\
\text { diode traffic } \\
\text { signals } \\
\text { ** Mandatory } \\
\text { minimum energy } \\
\text { performance } \\
\text { standards } \\
\text { ** Methane } \\
\text { capture and re-use } \\
\text { ** Carbon trading }\end{array}$ & $\begin{array}{l}\text { ** Energy } \\
\text { efficiency } \\
\text { standards } \\
* * \text { Methane } \\
\text { capture and re- } \\
\text { use } \\
\text { ** Solar feed in } \\
\text { tariff } \\
\text { ** Solar hot } \\
\text { water rebate } \\
\text { ** Energy } \\
\text { efficient } \\
\text { streetlights } \\
\text { ** Mandate } 4 \\
\text { star rating for } \\
\text { new buildings }\end{array}$ & $\begin{array}{l}\text { ** Energy } \\
\text { efficiency } \\
\text { standards } \\
\text { ** Renewable } \\
\text { energy targets } \\
\text { ** Clean coal } \\
\text { ** Smart meters } \\
\text { ** Mandatory } \\
\text { minimum } \\
\text { energy } \\
\text { performance } \\
\text { standards }\end{array}$ & $\begin{array}{l}\text { ** } 100 \% \\
\text { renewable energy } \\
\text { target } \\
* * \text { Energy } \\
\text { efficiency } \\
\text { ** Solar feed in } \\
\text { tariff } \\
\text { ** Light emitting } \\
\text { diode traffic } \\
\text { signals }\end{array}$ & $\begin{array}{l}\text { ** Energy } \\
\text { efficiency } \\
\text { standards } \\
\text { ** Solar feed in } \\
\text { tariff } \\
\text { ** Renewable } \\
\text { energy targets } \\
\text { ** Solar hot } \\
\text { water for new } \\
\text { homes } \\
\text { ** Smart meters } \\
\text { ** Solar panel } \\
\text { installations on } \\
\text { government } \\
\text { buildings }\end{array}$ & $\begin{array}{l}\text { ** Energy } \\
\text { efficiency } \\
\text { standards } \\
* * \text { Renewable } \\
\text { energy targets } \\
* * \text { Gas-fired } \\
\text { power-station } \\
\text { ** Clean coal } \\
\text { ** New } \\
\text { government- } \\
\text { funded wind-farms } \\
* * \text { Solar hot water } \\
\text { rebate }\end{array}$ & $\begin{array}{l}* * \text { Energy } \\
\text { efficiency } \\
\text { incentives }\end{array}$ \\
\hline $\begin{array}{l}\text { Transport } \\
\text { changes }\end{array}$ & $\begin{array}{l}\text { ** Public transit } \\
\text { upgrades } \\
\text { ** Fuel efficient } \\
\text { vehicle registration } \\
\text { discount } \\
\text { ** Mandate }\end{array}$ & $\begin{array}{l}\text { ** Public transit } \\
\text { upgrades } \\
\text { ** Clean car } \\
\text { consumer guide } \\
\text { ** Alternative } \\
\text { fuel ferries }\end{array}$ & $\begin{array}{l}* * \text { Public transit } \\
\text { upgrades } \\
* * \text { Fuel efficient } \\
\text { vehicle } \\
\text { registration } \\
\text { discount }\end{array}$ & $\begin{array}{l}\text { ** Public transit } \\
\text { upgrades } \\
\text { ** Government } \\
\text { hybrid vehicles } \\
\text { ** Modal shift } \\
\text { education }\end{array}$ & $\begin{array}{l}\text { ** Public transit } \\
\text { upgrades } \\
* * \text { Government } \\
\text { electric vehicles } \\
\text { ** Modal shift } \\
\text { education }\end{array}$ & $\begin{array}{l}* * \text { Alternative } \\
\text { fuel bus fleet } \\
* * \text { Government } \\
\text { alternative-fuel } \\
\text { vehicles } \\
* * \text { Modal shift }\end{array}$ & $\begin{array}{l}* * \text { Public transit } \\
\text { upgrades } \\
* * \text { Modal shift } \\
\text { education program } \\
* * \text { Alternative fuel } \\
\text { bus fleet }\end{array}$ & None \\
\hline
\end{tabular}




\begin{tabular}{|c|c|c|c|c|c|c|c|c|}
\hline & Queensland & New South Wales & $\begin{array}{l}\text { Australian } \\
\text { Capital } \\
\text { Territory } \\
\end{array}$ & Victoria & Tasmania & South Australia & $\begin{array}{l}\text { Western } \\
\text { Australia }\end{array}$ & $\begin{array}{l}\text { Northern } \\
\text { Territory }\end{array}$ \\
\hline & $\begin{array}{l}\text { ethanol fuel blend } \\
* * \text { Cycle network } \\
\text { upgrades } \\
* * \text { Modal shift } \\
\text { education program } \\
\text { ** Alternative fuel } \\
\text { bus fleet }\end{array}$ & $\begin{array}{l}\text { ** Transit } \\
\text { integration }\end{array}$ & $\begin{array}{l}\text { ** Alternative } \\
\text { fuel bus fleet } \\
* * \text { Cycle } \\
\text { network } \\
\text { upgrades } \\
\text { ** Free bus } \\
\text { travel for bike } \\
\text { riders } \\
\text { ** Replace } \\
\text { government } \\
\text { fleet vehicles }\end{array}$ & $\begin{array}{l}\text { program } \\
* * \text { Alternative } \\
\text { fuel bus fleet }\end{array}$ & $\begin{array}{l}\text { program } \\
* * \text { Alternative } \\
\text { fuel bus fleet } \\
* * \text { Fuel efficient } \\
\text { vehicle } \\
\text { registration } \\
\text { discount } \\
\text { ** Driver } \\
\text { education }\end{array}$ & $\begin{array}{l}\text { education } \\
\text { program }\end{array}$ & $\begin{array}{l}\text { ** Cycle network } \\
\text { upgrades } \\
* * \text { Subsidy for } \\
\text { LPG fuel } \\
\text { conversion subsidy } \\
\text { **Investigating } \\
\text { regenerative } \\
\text { braking in trains } \\
* * \text { Investigating } \\
\text { vehicle emissions } \\
\text { testing }\end{array}$ & \\
\hline $\begin{array}{l}\text { Agricultural } \\
\text { responses }\end{array}$ & $\begin{array}{l}\text { ** Managing } \\
\text { livestock and soil } \\
\text { emissions } \\
\text { ** Clearing offsets } \\
\text { ** Promoting farm } \\
\text { forestry }\end{array}$ & $\begin{array}{l}\text { ** Managing } \\
\text { livestock and soil } \\
\text { emissions } \\
\text { ** Farmer training } \\
\text { ** Promoting } \\
\text { farm forestry }\end{array}$ & None & $\begin{array}{l}\text { ** Ecosystem } \\
\text { services market } \\
\text { valuation } \\
\text { ** Promoting } \\
\text { 'healthy soils' } \\
\text { Promoting } \\
\text { vegetation } \\
\text { protection }\end{array}$ & $\begin{array}{l}\text { ** Researching } \\
\text { sustainable yields } \\
* * \text { Food impact } \\
\text { report } \\
* * \text { Climate-smart } \\
\text { farms } \\
* * \text { Emissions } \\
\text { measurement } \\
\text { tools }\end{array}$ & $\begin{array}{l}* * \text { Seed } \\
\text { conservation } \\
* * \text { Trialling new } \\
\text { crops } \\
* * \text { Protecting } \\
\text { viable } \\
\text { agricultural land } \\
\text { ** Support tools } \\
\text { for farm } \\
\text { management }\end{array}$ & $\begin{array}{l}* * \text { Researching } \\
\text { alternative } \\
\text { agriculture } \\
\text { **Promoting farm } \\
\text { forestry }\end{array}$ & $\begin{array}{l}* * \text { Drought } \\
\text { tolerant crops } \\
* * \\
\text { Monitoring } \\
\text { and } \\
\text { controlling } \\
\text { pests and } \\
\text { weeds }\end{array}$ \\
\hline $\begin{array}{l}\text { Health } \\
\text { program }\end{array}$ & $\begin{array}{l}\text { Researching health } \\
\text { impacts }\end{array}$ & $\begin{array}{l}\text { Promoting } \\
\text { hospital co-energy } \\
\text { generation }\end{array}$ & None & $\begin{array}{l}* * \text { Developing a } \\
\text { heat-wave } \\
\text { emergency plan } \\
\text { ** 'Greening' } \\
\text { hospitals and } \\
\text { aged-care }\end{array}$ & None & None & $\begin{array}{l}\text { Reviewing } \\
\text { potential impacts }\end{array}$ & None \\
\hline $\begin{array}{l}\text { Commercial / } \\
\text { Industrial }\end{array}$ & $\begin{array}{l}* * \text { Energy } \\
\text { efficiency audits } \\
* * \text { New energy } \\
\text { efficiency } \\
\text { standards }\end{array}$ & $\begin{array}{l}\text { Voluntary } \\
\text { greenhouse rating } \\
\text { scheme }\end{array}$ & $\begin{array}{l}\text { Use national } \\
\text { building code }\end{array}$ & $\begin{array}{l}\text { ** New energy } \\
\text { efficiency } \\
\text { standards }\end{array}$ & None & $\begin{array}{l}* * \text { New energy } \\
\text { efficiency } \\
\text { standards } \\
\text { ** Foster micro- } \\
\text { wind turbine } \\
\text { technology }\end{array}$ & None & None \\
\hline Housing & $\begin{array}{l}\text { ** Demonstration } \\
\text { sustainability } \\
\text { houses } \\
* * \text { Requirements } \\
\text { for water and }\end{array}$ & $\begin{array}{l}\text { ** Retrofit state- } \\
\text { owned housing } \\
\text { with energy and } \\
\text { water efficient } \\
\text { fixtures }\end{array}$ & $\begin{array}{l}\text { ** Mandatory } \\
\text { disclosure of } \\
\text { energy } \\
\text { efficiency at } \\
\text { time of sale }\end{array}$ & $\begin{array}{l}\text { ** Retrofit state- } \\
\text { owned housing } \\
\text { with energy and } \\
\text { water efficient } \\
\text { fixtures }\end{array}$ & $\begin{array}{l}* * \text { Energy } \\
\text { efficiency audits } \\
* * \text { Means-tested } \\
\text { insulation } \\
\text { upgrade rebates }\end{array}$ & $\begin{array}{l}* * \text { System to } \\
\text { rate residential } \\
\text { sustainability }\end{array}$ & $\begin{array}{l}* * \text { Introducing } 5 \\
\text { star rating for all } \\
\text { new housing } \\
\text { ** Water } \\
\text { efficiency }\end{array}$ & None \\
\hline
\end{tabular}




\begin{tabular}{|c|c|c|c|c|c|c|c|c|}
\hline & Queensland & New South Wales & $\begin{array}{l}\text { Australian } \\
\text { Capital } \\
\text { Territory } \\
\end{array}$ & Victoria & Tasmania & South Australia & $\begin{array}{l}\text { Western } \\
\text { Australia }\end{array}$ & $\begin{array}{l}\text { Northern } \\
\text { Territory }\end{array}$ \\
\hline & $\begin{array}{l}\text { energy efficiency } \\
* * \text { Phase out of } \\
\text { electric hot water } \\
\text { systems and } \\
\text { rebates for gas a } \\
\text { solar }\end{array}$ & $\begin{array}{l}\text { ** Education } \\
\text { campaign on air- } \\
\text { conditioner use }\end{array}$ & $\begin{array}{l}* * \text { Mandatory } 5 \\
\text { star rating for } \\
\text { all new housing }\end{array}$ & $\begin{array}{l}\text { ** Mandatory } 5 \\
\text { star rating for all } \\
\text { new housing } \\
\text { ** Gas-boosted } \\
\text { solar hot water } \\
\text { for all new } \\
\text { houses } \\
\text { ** Introducing } \\
\text { mandatory } \\
\text { disclosure of } \\
\text { energy } \\
\text { efficiency at } \\
\text { time of sale }\end{array}$ & $\begin{array}{l}* * \text { Mandatory } \\
\text { minimum energy } \\
\text { efficiency } \\
\text { standards }\end{array}$ & & requirements & \\
\hline $\begin{array}{l}\text { Land use } \\
\text { planning } \\
\text { responses }\end{array}$ & $\begin{array}{l}\text { ** Draft South } \\
\text { East Queensland } \\
\text { Regional Plan } \\
\text { (2009-2031) } \\
\text { ** State planning } \\
\text { policy under } \\
\text { development } \\
\text { **State Coastal } \\
\text { Management Plan } \\
\text { ** Coastal } \\
\text { vulnerability } \\
\text { assessment } \\
\text { ** Storm gauge } \\
\text { and tide buoys } \\
\text { being installed } \\
\text { ** Disaster } \\
\text { management plan } \\
\text { under review }\end{array}$ & $\begin{array}{l}* * \text { NSW } \\
\text { metropolitan } \\
\text { strategy } \\
\text { ** Streamlining } \\
\text { approvals process } \\
\text { for low-emissions } \\
\text { technology } \\
\text { **Introducing } \\
\text { planning } \\
\text { guidelines } \\
\text { promoting } \\
\text { walking and } \\
\text { cycling } \\
\text { ** Promoting a } \\
\text { hydrogen } \\
\text { economy } \\
\text { ** Developing } \\
\text { infrastructure to } \\
\text { facilitate waste to } \\
\text { energy technology }\end{array}$ & $\begin{array}{l}\text { ** Fostering } \\
\text { integrated land } \\
\text { use and } \\
\text { transport } \\
\text { planning } \\
\text { ** Regional } \\
\text { vulnerability } \\
\text { assessment } \\
\text { ** Assessing } \\
\text { climate change } \\
\text { impacts in } \\
\text { urban areas } \\
\text { ** Undertaking } \\
\text { social impact } \\
\text { analysis } \\
\text { ** Draft water } \\
\text { sensitive-urban } \\
\text { design } \\
\text { guidelines }\end{array}$ & $\begin{array}{l}* * \text { Melbourne } \\
2030 \text { strategic } \\
\text { plan } \\
\text { ** Draft } \\
\text { Victorian } \\
\text { coastal strategy } \\
\text { Reviewing } \\
\text { development } \\
\text { standards for } \\
\text { river protection } \\
\text { ** Green-wedge } \\
\text { management } \\
\text { plans } \\
\text { ** New urban } \\
\text { growth } \\
\text { boundary } \\
\text { ** Transit } \\
\text { oriented } \\
\text { development }\end{array}$ & $\begin{array}{l}\text { ** Introducing } \\
\text { climate change } \\
\text { impact statements } \\
\text { into decision- } \\
\text { making } \\
* * \text { Assessing } \\
\text { coastal risks } \\
\text { ** Including } \\
\text { climate change in } \\
\text { regional planning } \\
\text { ** Promoting } \\
\text { transit integrated } \\
\text { planning } \\
\text { ** Restricting } \\
\text { development in } \\
\text { floodplains } \\
\text { ** Hazard } \\
\text { management and } \\
\text { response planning }\end{array}$ & $\begin{array}{l}* * \text { Reviewing } \\
\text { vulnerability of } \\
\text { critical } \\
\text { infrastructure } \\
\text { **Reviewing } \\
\text { hazards and } \\
\text { emergency } \\
\text { planning } \\
\text { ** Mapping } \\
\text { coastal } \\
\text { vulnerability } \\
\text { **Fostering } \\
\text { transit-oriented } \\
\text { development } \\
\text { **Removing } \\
\text { development } \\
\text { approval } \\
\text { requirements for } \\
\text { solar panel } \\
\text { installation }\end{array}$ & $\begin{array}{l}* * \text { State coastal } \\
\text { planning strategy } \\
\text { **Network city } \\
\text { strategy } \\
\text { ** Promoting } \\
\text { transit-oriented } \\
\text { development } \\
\text { **Strengthening } \\
\text { residential design } \\
\text { code to include } \\
\text { water sensitive } \\
\text { urban design and } \\
\text { passive solar } \\
\text { design }\end{array}$ & $\begin{array}{l}\text { **Avoiding } \\
\text { building in } \\
\text { storm surge } \\
\text { zones } \\
\text { **Improved } \\
\text { cyclone- } \\
\text { resistance } \\
\text { building } \\
\text { codes } \\
* * \text { Guidelines } \\
\text { for climate- } \\
\text { oriented } \\
\text { design }\end{array}$ \\
\hline
\end{tabular}


Figure 1 Gold Coast built environment

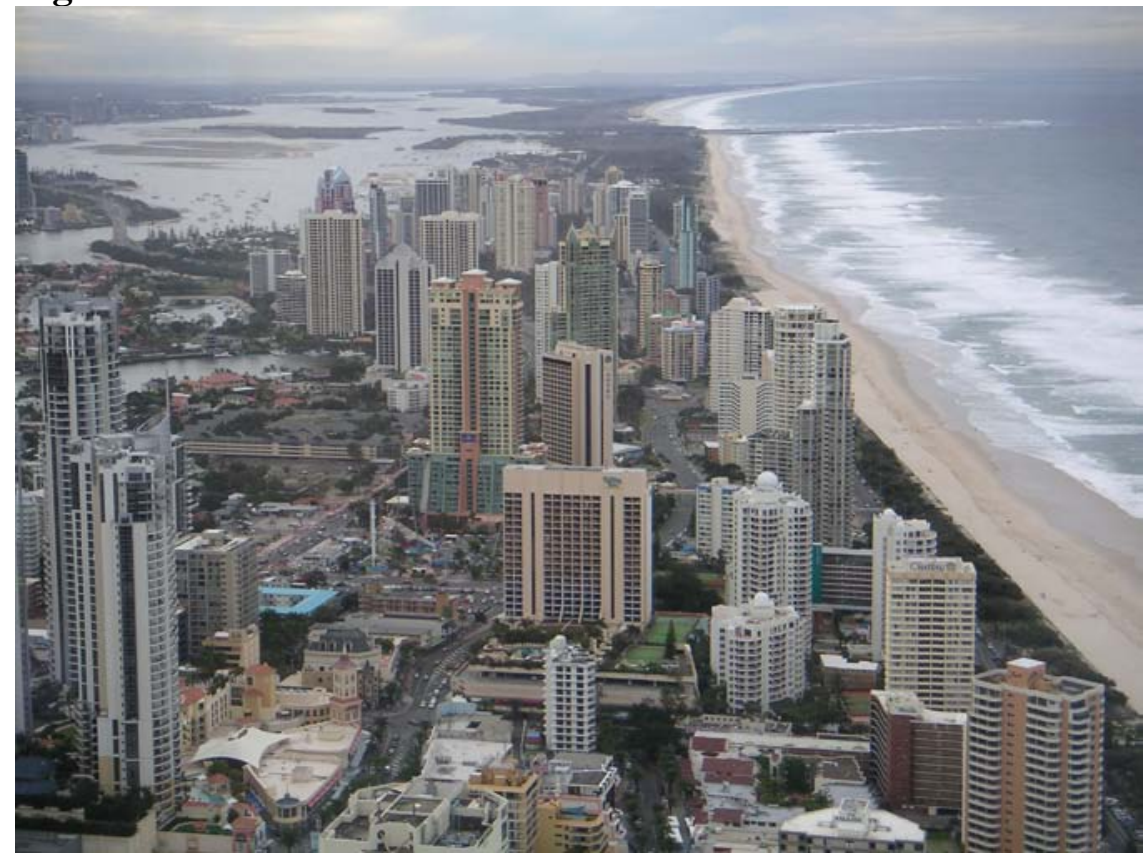

Photo: J. Byrne

Figure 2 Sustainable house, Gold Coast

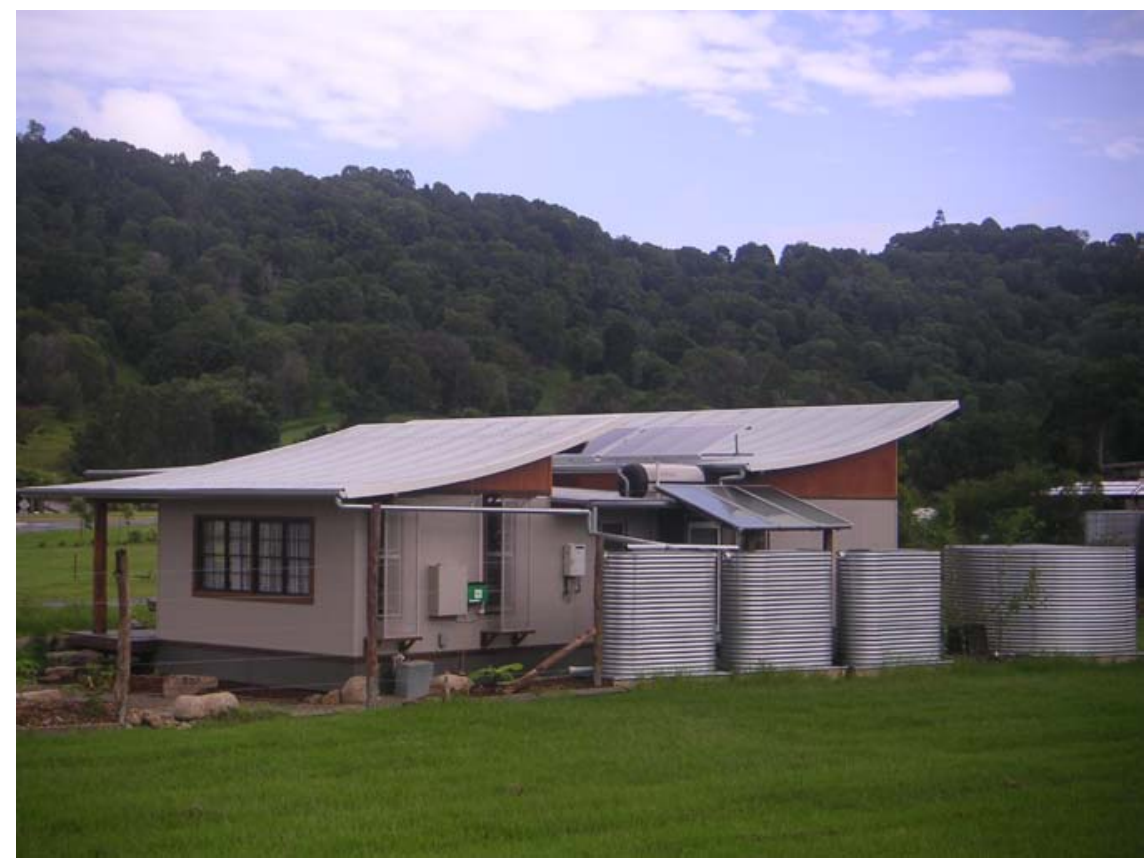

Photo: J. Byrne 